\title{
CRITICAL THINKING
}

\section{Matt Morgan: Hold onto your red thread}

\author{
Matt Morgan intensive care consultant \\ University Hospital of Wales
}

My Welsh comprehensive school education stood me in good stead for rugby, but less so for Greek mythology. I may have come late to the classics, but I have recently read about how Theseus defeated the Minotaur and found his way out from the labyrinth and back to safety, by following a thread of red wool that he had tied to the entrance.

No matter where you work in the healthcare system, this year is going to be very hard. As the covid-19 pandemic spreads around the world we may lose patients, colleagues, friends, and even members of our family. Yet we need to focus our energy on the things we can control and not on the things we cannot. And so, in this time of turbulence, the most important thing that we must be sure not lose is ourselves.

The deeper we go into the labyrinth of work, the more important our own "red thread" becomes. For some of us, that thread may be tied to exercise- a bike ride to work or a run through the park. For others it will be tied to music, or cooking, or spending time in the garden. Many of us throw our energy into caring for our children or our pets when we come home, after a long day spent working in protective clothing. Others may tie the red thread to red wine, but they need to be careful that the glass doesn't smash as the thread is tugged ever harder.

\section{Safely stepping away}

Just as we need to check whether it's safe to approach when treating infected patients, we should also check that we can safely step away after we are done with our day's work. And, as we walk back through the doors between our places of work and our places of life, we need to remember to hold on tightly to that red thread, now more than ever.

Make the time to follow the thread's path back to the place it was tied, and try to look around you as you make that journey. Put your phone back in your pocket, put away the worries about patients that you carry around in the back of your mind, and grab that red thread with both hands, even if just for a little while. And if the thread has become loose, if it is untied, or if you are already too deep into the labyrinth, ask for help to find another thread. Don't lose yourself.

Competing interests: I have read and understood BMJ policy on declaration of interests and declare that I have no competing interests.

Provenance and peer review: Commissioned; not externally peer reviewed.

Matt Morgan is an honorary senior research fellow at Cardiff University, consultant in intensive care medicine, research and development lead in critical care at University Hospital of Wales, and an editor of BMJ OnExamination.

Published by the BMJ Publishing Group Limited. For permission to use (where not already granted under a licence) please go to http://group.bmj.com/group/rights-licensing/ permissions 